Cronfa - Swansea University Open Access Repository

This is an author produced version of a paper published in :

British Journal of Hospital Medicine

Cronfa URL for this paper:

http://cronfa.swan.ac.uk/Record/cronfa29715

\title{
Paper:
}

Chamberlain, J. (2009). Portfolio-based appraisal: superficial or useful?. British Journal of Hospital Medicine, 70(11), 614-615.

http://dx.doi.org/10.12968/hmed.2009.70.11.45044

This article is brought to you by Swansea University. Any person downloading material is agreeing to abide by the terms of the repository licence. Authors are personally responsible for adhering to publisher restrictions or conditions. When uploading content they are required to comply with their publisher agreement and the SHERPA RoMEO database to judge whether or not it is copyright safe to add this version of the paper to this repository. http://www.swansea.ac.uk/iss/researchsupport/cronfa-support/ 


\section{Portfolio-based appraisal: superficial or useful?}

A portfolio is a 'dossier of evidence collected over time that demonstrates a doctor's education and practice achievements' (Wilkinson et al 2002: 371). In addition to annual NHS appraisal, paper-based and electronic portfolios are now used within medicine to support performance appraisal throughout medical school, the foundation programme as well as higher specialist training. They will also play a role in revalidation as it is gradually rolled out across the UK over the next two years.

It is argued portfolio-based appraisal is personally and organisationally beneficial. For example it is claimed NHS appraisal gives a clinician the opportunity to take time out from their busy work schedule and with input from management and work colleagues identify how they are performing clinically as well as how local service provision can be improved (Black 2002).

Furthermore it is claimed portfolio-based appraisal not only improves individual and organisational operational effectiveness but also acts as an open and transparent quality assurance tool (Davis et al 2001). Certainly its appeal for regulatory bodies such as the GMC primarily lies in its ability to operate as a bureaucratic career record which provides ongoing auditable evidence of work-task competence (or not) and compliance (or not) with best-practice performance frameworks, guidelines and protocols (Bruce 2007).

\section{Appraising Portfolio Appraisal}

Yet the reality of portfolio-based performance appraisal often fails to live up to the expectation. Take my own research (see Chamberlain 2009). This investigated doctors experiences of using a portfolio to demonstrate their continued fitness to practice to their peers, in addition to documenting and assessing the progress of the medical students and foundation trainees they mentor during clinical rotations.

The clinicians I spoke to agreed appraisal does create an audit trail which in principle is making them more accountable for their actions. They also agreed that appraisal could have a positive impact upon professional development and career planning. But their accounts nevertheless revealed that appraisal tended to be conducted somewhat ritualistically. Indeed they and their peers were to varying degrees adopting a stance of 'paperwork compliance' toward it.

Paperwork compliance occurs when the completion requirements of appraisal have been fulfilled, with relevant sections of a portfolio completed and an appraisee signed-off by their appraiser as either having meet minimum performance criteria or not. However formal appraisal procedures have not been adhered to by the appraiser. Instead they have adopted a highly superficial tick-box approach toward their completion. I will discuss the reasons why paperwork compliance occurs shortly.

\section{Rituals of Employment}

The concept of paperwork compliance draws attention to the fact that if appraisals fail to meet their manifest purpose, they succeed rather as rituals of employment' (Pym 1973: 233). Certainly my research is not the first to discover that appraisal (portfolio-based or otherwise) does not necessarily deliver what it promises in terms of increased worker productivity, organisational efficiency and institutional transparency and accountability.

Both Redman et al (2000) and Smith (2005) have noted that appraisal possesses a tendency to operate superficially within medicine, with doctors engaging in creative 'game playing' toward its procedural requirements. Paperwork compliance 
is an example of such game playing. Yet appraisal is just a tool and it is the application of the tool that is the key to its success. So with revalidation firmly on the immediate horizon I argue for the need to address the following three issues with the aim of turning portfolio-based appraisal into a more useful exercise for clinicians.

\section{Addressing the Key Issues}

First is the tendency for its outcomes to lack follow-up. My research showed that clinicians tended to not fully engage with portfolio-based appraisal because they felt it more often than not lacked impact in terms of generating real long-term change on the shop floor. Yet if appraisal has little direct impact upon an individuals day to day working conditions then a growing disenchantment with the process is to be expected (Bruijn 2001).

Resources must be set aside to ensure that where possible appraisal outcomes do impact upon service provision. Clearly this is a system wide challenge which must be addressed at local and national clinical governance levels. While only time will tell if changes to annual NHS appraisal bound up with the implementation of revalidation will also help address this issue.

Second is the need for appraisers to be formerly trained and proactively monitored by governing regulatory bodies. Time and time again clinicians accounts of the management of appraisal showed that appraisers by and large lacked the knowledge and skills necessary to manage appraisal neutrally, efficiency and effectively. Furthermore clinicians frequently had received little (and in many cases no) formal training in how to approach portfolio-based appraisal for trainees.

Here the appraisal literature is unequivocal. The possession of a position of authority and mastery of subject specific knowledge and skills are not in themselves enough to qualify an individual to be an appraiser. Neither for that matter is the periodic completion of some form of short-lived annual 'in house' training program.

The successful management of appraisal procedures and processes requires appraisers complete properly accredited training programs linked to a clear career pathway and reward system, have their management of the appraisal process subject to appropriate independent multi-disciplinary quality assurance mechanisms, and finally are required to periodically subject themselves to formal summative review and upgrade their knowledge and skills as necessary (Armstrong 2005).

Clearly this possesses considerable resource implications, but such matters must be met head on by the GMC in particular if performance appraisal (portfoliobased or otherwise) is to become a meaningful exercise and generate real cultural change within medicine.

Third is the need for individual clinicians themselves to put aside whatever doubts they have and proactively engage with appraisal no matter what current problems and limitations they feel it possesses. Fundamentally portfolio-based appraisal is about promoting good professional practice. It publicly records a clinician's willingness to place their patient's needs and interests above their own through being critically reflective of their clinical performance and where necessary admitting to mistakes and learning from them (Wilkinson 2002).

It was an unfortunate fact of my research that only a small number of clinicians recognised this, the majority preferring instead to focus upon appraisals negative aspects and by and large viewing it as nothing more than an onerous paper filling exercise.

Yet it was equally reassuring to learn that those clinicians who did view appraisal positively argued that in spite of its current problems and limitations, or how 
their appraiser handled the appraisal process, their personal commitment to making it work for them had helped them use it to identify how they are doing in their job as well as decide what the next steps in their career should be. Clearly such experiences need to be shared as they show the true value of the tool as an agent for positive change.

\section{Conclusion}

Portfolio-based performance appraisal is here to stay (Donaldson 2008). In these risk aware times it acts as one of medicine's " visible markers" of trust [which as]...tools of bureaucratic regulation fulfil [a] function as signifiers of quality' (Kuhlmann 2006: 617). The tendency toward ritualised engagement with its procedural requirements must therefore be addressed through tackling head on appraisals lack of direct long-term impact on professional practice and day to day working conditions.

Formal training career pathways and reward systems for appraisers must also be established, as should an independently managed multi-disciplinary quality assurance mechanisms to ensure equity and public accountability. This must all be done in an open and transparent manner, particularly as revalidation gradually 'goes live' over the next two years. Only then will portfolio-based performance appraisal in all its forms finally live up to expectation and become a useful tool for clinicians.

\section{Key Points}

- Portfolio-based appraisal is now used during medical school, the foundation programme, in higher specialist training and annual NHS appraisal. It will also play a role in revalidation.

- Portfolio-based appraisal promises increased worker productivity, organisational efficiency and institutional transparency and accountability.

- However research shows clinicians often view it as a paper chasing exercise, adopting a stance of 'paperwork compliance' toward it.

- Adequate resourcing is needed so portfolio-based appraisal positively impacts upon clinical practice as well as a clinician's professional development and career planning.

- Formal training pathways and reward systems for appraisers and independently managed multi-disciplinary quality assurance mechanisms must also be established to support the implementation of portfolio-based appraisal in all its forms.

\section{References}

Armstrong, M. (2005) Managing Performance London Institute of Personal Development

Black, D. (2002) Consultant Appraisal GMC News Supplement on Appraisal and Revalidation 1- 4. The GMC: London

Bruce, D.A. (2007) Regulation of Doctors BMJ (334): 436-37

Bruijn, H. (2001) Managing Performance in the Public Sector Routledge

Chamberlain, J.M. (2009) Doctoring Medical Governance: Medical Self-Regulation

in Transition Nova Science: New York

Davis, M.H, Friedman B.D, Harden, R.M, Howie, P, Ker, C, McGhee, MJ, Pipard, MJ and Snadden, D. (2001) Portfolio Assessment in medical students' final examinations Medical Teacher (23) 4: 231-250 
Donaldson, L. (2008) Revalidation the next steps London: Department of Health

Kuhlmann, E. (2006b) Traces of Doubt and Sources of Trust: Health Professions in an Uncertain Society Current Sociology, (54): 607-19

Pym, D. (1973) The Politics and Ritual of Appraisal Occupational Psychology (47): 231-235

Redman, T, Snape, E, Thompson, D and Ka-Ching, F.Y. (2000) Performance

Appraisal in an NHS hospital, Human Resource Management Journal 10 (1): 48-62

Smith, J. (2005) Shipman: Final Report, London: Department of Health

Snadden, D and Thomas, M. (1998) The Use of Portfolio Learning in Medical

Education Medical Teacher (20) 3: 244-265

Wilkinson, T.J, Challis, M, Hobma, S.O, Newble, D.I, Parbossingh, J.T, Sibbald, R.G and Wakefield, R. (2002) The Use of Portfolios for Assessment of the Competence and Performance of Doctors in Practice, Medical Education (36) 1:23-46 